Пачулия Ольга Зурабовна

канд. экон. наук, ассоциированный профессор Сухумский государственный университет г. Тбилиси, Грузия

DOI $10.21661 / r-115979$

\title{
THEORETICAL FRAMEWORK OF VERTICAL INTEGRATION IN STRATEGIC MANAGEMENT
}

Аннотация: интеграция стратегии создаёт устойчивое конкурентное преимущество, которое зависит от редкости и дороговизны (стоимости) имитации конкретной стратегии, выбранной фирмой. Вертикальную интеграцию назад и вперед может осуществить индустриальная компания, которая борется за добывание конкурентного преимущества и повышает шанс, чтобы гарантировать редкость и сложность имитации и дорогостоимость (расходность) ресурсов. Указанный труд исследует, как создаёт экономию масштаба конкретная стратегия и рассматривает её теоретически. Объектом исследования этого труда является выявление, насколько создаёт стратегия вертикальной интеграции ценность для бизнеса и каковы причины и последствия вертикальной интеграции на рынке.

Ключевые слова: управление, стратегия, интеграџия, типы.

Abstract: integration strategy to create sustainable competitive advantage depends on the rarity and on the cost of imitability of a particular strategy chosen by a firm. Backward and forward vertical integration may be pursued by industry firms competing to achieve competitive advantage property and to increase the chance to guarantee rare, difficult to imitate and costly resources. This work investigates how these particular strategies create economies of scale and scope and discusses it theoretically. This paper has the objective to investigate if the vertical integration strategy makes value for business and what are the causes and consequences of market outcomes of vertical integration.

Keywords: management, strategy, integration, types. 
According to neoclassical economic theory, in a world characterized by perfectly competitive and informational efficient input and output product markets, transaction costs should be non-existent and no sustainable advantages can therefore be generated from being vertically integrated. Picard says, that transaction costs are the costs associated with each transaction that a firm makes (Picard, 2002, p. 66). All firm, integrated or not, earn at best long-term returns that approximate their respective costs of capital. Any management action that by chance caused a positive deviation from the expected level of return is soon be eroded by competition's counterattack (Coase, 1988). However, vertical integration has been a recurring and often dominant strategy for enterprises in many different industries. Vertical integration still continues to be one of the favorite strategy for companies which wants to expanse their business. Based on this, the research question is: Does the vertical integration strategy make value for business? What are the causes and consequences of market outcomes of vertical integration?

According to theories, vertical integration can on the one hand promote efficiency by eliminating successive monopoly mark-ups, internalizing service, and mitigating contractual problems between firms (Williamson,1971; Grossman\&Hart, 1986). In Chipty's opinion this effect results in lower prices, higher sales and grater consumer welfare (Chipty, 2001).

Vertical integration can facilitate the strategic practice of market foreclosure, whereby an integrated firm denies rivals access to markets in order to gain greater market power. Chipty suggests that this raises the prices of final goods, thereby harming consumers (Chipty, 2001).

Vertical integration integrates a company with the units supplying raw materials to it (backward integration), or with the distribution channels that carry its products to the end-consumers (forward integration).

Forward vertical integration in business is when a manufacturer decides to perform distribution and/or retail functions within the distribution channel. This is commonly referred to as «eliminating the middle man," as manufacturers may cut out the wholesaler to sell directly to retailers or the retailer to sell directly to customers. These cause some problems and in contrary, it has benefits. 
First of all a common benefit of forward integration is that manufacturers can reduce steps in the distribution process and sell higher up in the distribution process. This can benefit both the manufacturing firm and the retailer or customer it sells. Manufacturers can also gain more control over the distribution and pricing of their products by selling to retailers or customers.

A main reason not all manufacturers engage in wholesale or retail is because they lack expertise in these functions. Fathermore, lack of expertise causes production quality risks, operational risks, management risks and other crucial risks in future. Manufacturers specialize in developing and producing products and then passing them on to distribution companies. Also, when a manufacturer vertically integrates into distribution or retail, it has to store inventory for a longer period of time. This requires additional warehouse space and more employees to manage the facilities and inventory. One can be concluded, implementing forward vertical integration strategy needs careful management planning and marketing.

As for backward integration, when a company implements backward integration it controls subsidiaries (suppliers). Controls of these subsidiaries are intended to create a stable supply of inputs and ensure a consistent quality in their final product. For example, a supermarket may acquire control of farms to ensure supply of fresh vegetables (backward integration) or may buy vehicles to smoothen the distribution of its products (forward integration). A car manufacturer may acquire tyre and electrical-component factories (backward integration) or open its own showrooms to sell its vehicle models or provide after-sales service (forward integration). Backward integration is aimed for companies, which want to control distribution centers and retails where its products are sold. 


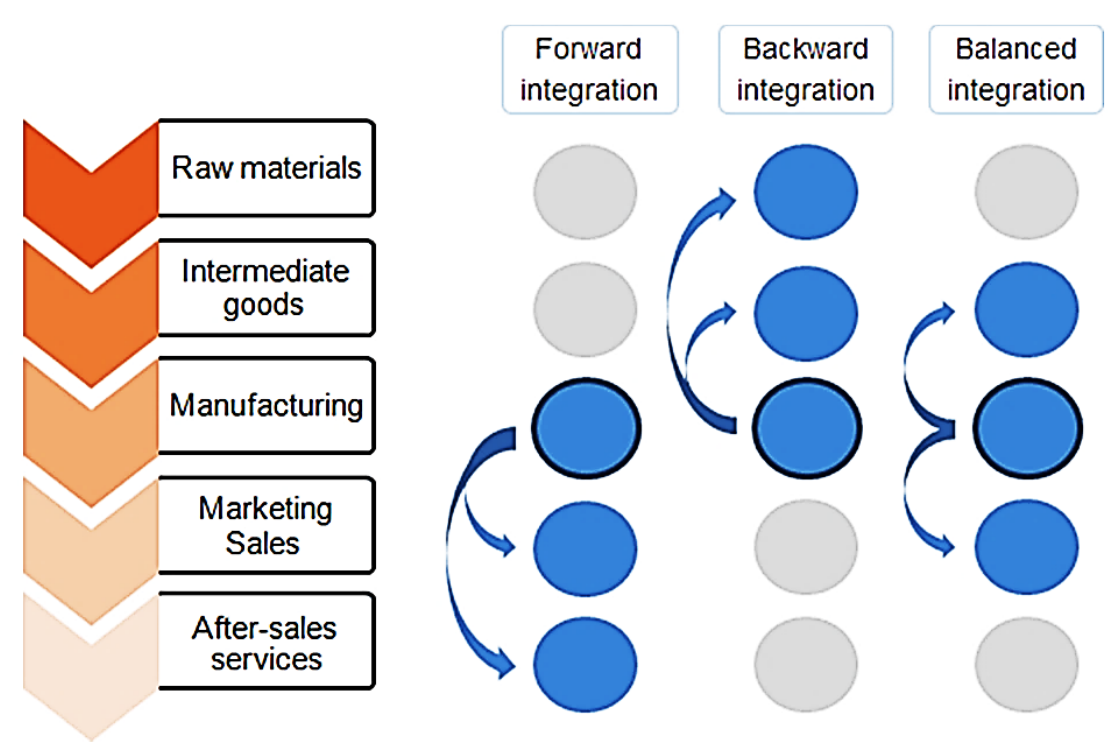

Figure 1. Types of integration strategies

There is a third type of vertical integration, called balanced integration, which is a judicious mix of backward and forward integration strategies. Below, Figure $\mathrm{n}$ shows types of vertical integration. For instance, if the company's has manufacturing, marketing sales and after-sales services it implements the forward integration strategy. If the company's has manufacturing, intermediate goods and raw materials, the company used the backward integration strategy. If the company has manufacturing, intermediate goods and marketing, sales the company implements balanced integration (mixed) strategy.

Vertical integration examples are World Brands like Ford, Tesco, Apple and etc. For instance, Ford river rouge complex: Tire complex, Glass and Metal complex. Tesco: livestock, fruits and vegetables. Apple Inc: Processor and software. So, one question can be raised: When is vertical integration attractive for a business?

To sum up the benefits of integration strategy, we suggest several factors affect the decision-making that goes into backward and forward integration. A company may go in for these strategies in the following scenarios:

1. The current suppliers of the company's raw materials or components, or the distributors of its end products, are unreliable (choose backward integration).

2. The prices of raw materials are unstable or the distributors charge high fees (choose backward integration). 
3. The suppliers or distributors earn big margins (choose backward integration).

4. The company has the resources to manage the new business that is currently being taken care of by the suppliers or distributors.

5. The industry is expected to grow significantly.

According to Galbraith firm's center of gravity is usually the point at which the company started. After a firm establishes well in this point it can move forward or backward along the value chain to reduce costs, access to raw material and guarantee distribution. This process is Vertical Integration. Indian examples of companies with strategic internet are late Dhirubai Ambani's Reliance group with the strategic intent of being a global leader of being the lowest cost producer of polyester products a status achieved with vertical integration and operational effectiveness.

Vertical integration strategy has its disadvantages. Undoubtfully there are some drawbacks of vertical integration. For instance, the quality of goods supplied earlier by external sources may fall because of a lack of competition. Moreover, flexibility to increase or decrease production of raw materials or components may be lost as the company may need to sustain a level of production in pursuit of economies of scale. Besides, it may be difficult for the company to sustain core competencies as it focuses on the integration of the new units.

However, there are alternatives to vertical integration, such as purchases from the market (of tyres, for example) and short- and long-term contracts (for showrooms and with service stations, for example).

\subsection{Company GT-Group and Forward Vertical Integration Strategy}

In 2007, a new company, GT Motors ltd. is joining the holding. GT Motors ltd. exclusively represents some leading automotive brands, as Ford, Land Rover, Jaguar and Suzuki, in Georgia. GT Motors import passenger cars from manufacturers, to Georgian and provides customers with full technical and warranty services.

«GT Group» daughter company «GT Motors» is the exclusive representative of Ford-'s, Land Rover and Suzuki in Georgia, which adds a significant competitive advantage to the company compared to other automobile importing companies and create some value for the company. Moreover, the company owns a modern, European 
standard Motor Show salons, where the latest models of all three automobile brands are exhibited. Renewed vehicles are constantly offered to customers, that creates additional value for the company's favor, as it increases the chances of making profit, since the company is the exclusive importer of Ford, Land Rover and Suzuki. In our views, it is difficult for competitors to copy and it is the rare resource for the company. Based on VRIO analysis, we can conclude, that thanks to just one subsidiary of the company (GT-motors), the company gains at least a temporary advantage over competitors. Unfortunately, it is hard to evaluate the long-term advantages of the company.

GT group enlarged his business and in order to become closer to the customer, it began the automotive service. The GT group founded the center, which is equipped with an auto - diagnostic and mechanical equipment, furthermore center fully meets the quality standards provided by the automakers. The company chose a strategy which is profitable double time more than usual: High-quality standards (of services and products) and vertical integration. First of all, high-quality adds value to the company and is profitable, it attracts the customer and is aimed for customer satisfaction. Furthermore, vertical integration strategy helped the company to grow earnings and make the company business portfolio more attractive.

The GT group is distinguished with human resources training. In order to deliver a high level of service to customers, the company holds training to its employees with training opportunities, where they are trained and take the latest technical information on modern service systems.

\section{Conclusion}

Based on a theoretical overview of integration strategy and evidences from business, horizontal integration strategy is a dominant strategy for enterprises in many different industries, it raises a big interest in stakeholders of the grand strategy. Based on this, the research question was: Does the vertical integration strategy make value for business? What are the causes and consequences of market outcomes of vertical integration? As we found out, vertical integration strategy created additional value for the 
company's favor, as it increased the chances of making profit. Moreover, vertical integration is recommended to be used together with other strategies, for example exclusiveness or diversification, it helps to can gain market power and gain over competitors. As we concluded, management needs careful market analyze before choosing a vertical integration strategy, as it has to take into consideration risks associated with this strategy, but with well managed vertical integration strategy consequences are beneficial for business.

\section{References}

1. Caldeira A. Vertical Integration and Corporate Diversification Strategies Study Based on Brazilian Industries / A. Caldeira, G.L. Moyses, P.D. Costantin, S. Lex, S.L. Bertoncello // The Business Association of Latin American Studies: Conference at Instituto de Emresa (Madrid, May 25-28). - 2005.

2. Cavalcanti M. Gestão estratégica de negócios: evolução, cenários, diagnostico e ação / M. Cavalcanti [et al.] // São Pau Paolo SP-Thomson Learning. - 2003.

3. Christopher A. Bartlett, Sumantra Ghoshal. Beyond Strategy to Purpose // Harvard Business Review, from the november-december 1994 ISSUE. - 1994.

4. Fiona Röder. Strategic Benefits and Risks of Vertical Integration in International Media Conglomerates and Their Effect on Firm Performance // Dissertation no. 3402, Difo-Druck Bamberg, the University of St. Gallen. - 2007.

5. Teece D.J. Explicating Dynamic Capabilities: Innovation Processes, Investment Decision-Making and Asset Cospecialization/Orchest ration in an (Economic) Theory of(Strategic) Management», Univerisity of California, Berkeley. 2005. 